ISSN 1392-3196 / e-ISSN 2335-8947

Zemdirbyste-Agriculture, vol. 105, No. 1 (2018), p. 71-78

DOI 10.13080/z-a.2018.105.010

\title{
Triterpenic acid content in the fruit peel of Malus $\times$ domestica Borkh. depends on the growing technology
}

\author{
Jonas VIŠKELIS ${ }^{1}$, Nobertas USELIS ${ }^{1,3}$, Mindaugas LIAUDANSKAS ${ }^{2}$, Valdimaras JANULIS ${ }^{2}$, \\ Pawel BIELICKI ${ }^{4}$, Toivo UNIVER ${ }^{5}$, Janis LEPSIS ${ }^{6}$, Darius KVIKLYS ${ }^{1}$ \\ ${ }^{1}$ Institute of Horticulture, Lithuanian Research Centre for Agriculture and Forestry \\ Kauno 30, Babtai, Kaunas distr., Lithuania \\ E-mail: j.viskelis@1sdi.lt
}

${ }^{2}$ Medicinal Academy, Lithuanian University of Health Sciences

Eivenių 4, Kaunas, Lithuania

${ }^{3}$ Aleksandras Stulginskis University

Studentų 11, Akademija, Kaunas distr., Lithuania

${ }^{4}$ Research Institute of Horticulture

Konstytucji 3 Maja 1/3, 96-100 Skierniewice, Poland

${ }^{5}$ Polli Horticultural Research Centre, Institute of Agricultural and Environmental Sciences,

Estonian University of Life Sciences

Polli 69108, Karksi-Nuia, Viljandi county, Estonia

${ }^{6}$ Institute of Horticulture, Latvia University of Agriculture

Pure 3124, Tukuma distr., Latvia

\begin{abstract}
Regardless of the numerous investigations of secondary metabolites, the impact of new growing technologies or individual technological means on fruit internal quality, particularly triterpene concentration in apple fruits has not been studied yet. Apple-tree (Malus $\times$ domestica Borkh.) growing technologies and geographical location of the growing site had clear effect on triterpene concentration in apple fruits. The effect of crop load, fruit location in apple-tree canopy, planting distance, apple-tree vegetative growth regulation and geographical location on triterpene content in apples was evaluated in 2015 and 2016. Four triterpenic compounds: corosolic, betulinic, oleonolic and ursolic acids, were quantified in apple peel. Triterpene accumulation in apple fruits was directly correlated with crop load, where $17 \%$ more total triterpenes were found at the highest crop load (12 fruits $\mathrm{cm}^{-2}$ trunk cross-sectional area (TCSA)) in comparison to the lowest crop load (4 fruits $\mathrm{cm}^{-2}$ TCSA). Higher concentration of triterpenes was found in the fruits harvested from the inner canopy of the apple-tree. Apple-tree growth regulation affected the synthesis of triterpenes - trunk incision decreased the amount of total triterpenes by $16 \%$ compared to the control and by $26 \%$ compared to summer pruning. Also, a trend of higher accumulation of triterpenes in fruits was found along with decreasing apple-tree planting distances. Colder climate and shorter vegetation period resulted in significantly higher contents of triterpenes in the fruits of cultivar 'Auksis' in Lithuania and Estonia compared to the fruits grown in Poland. The same trend, yet insignificant, was noticed for the cultivar 'Ligol'.
\end{abstract}

Key words: apple-tree, bioactive compounds, growing technologies.

\section{Introduction}

Apples are one of the most commonly consumed fruits in the world. Until now, development of apple growing and management technologies has been aimed at higher yields, fruit size and external quality (Hooge et al., 2017). In recent years, attention has

been focussed on fruit internal quality. Apples contain multiple nutrients and a variety of bioactive compounds, including phenols. Several studies have been conducted in Lithuania to explore the impact of rootstocks (Kviklys et al., 2014) and nutrition (Lanauskas et al., 2017) on

Please use the following format when citing the article:

Viškelis J., Uselis N., Liaudanskas M., Janulis V., Bielicki P., Univer T., Lepsis J., Kviklys D. 2018. Triterpenic acid content in the fruit peel of Malus $\times$ domestica Borkh. depends on the growing technology. Zemdirbyste-Agriculture, 105 (1): 71-78 DOI 10.13080/z-a.2018.105.0010 
the accumulation of phenols. Fruit phenol content has been investigated in the main apple cultivars grown in Lithuanian commercial orchards too (Liaudanskas et al., 2015; Raudonè et al., 2017). Research into other important bioactive compounds including triterpenes in apples is performed to a much lesser extent.

Triterpenes are a large group belonging to the terpenoid compounds and are well known for their pharmacological effects (Fontanay et al., 2008; Ikeda et al., 2008; Jang et al., 2009). Corosolic, betulinic, oleanolic and ursolic acids are typical representatives of pentacyclic triterpenes and they are widely distributed in the plant kingdom and in food products (Jäger et al., 2009; Muffler et al., 2011). Oleanolic and ursolic acids are found in the waxes of fruit and leaves (Qi et al., 2006; Koch, Ensikat, 2008). Triterpene content of various apple varieties (Andre et al., 2012), effect of rootstock, harvest maturity and storage methods (Lv et al., 2015) have been investigated, but there are no data on growing technologies or growing site effects on triterpene accumulation in apple fruits.

New findings about apple nutritional value are especially important while facing overproduction of apples in the world market and decrease of fruit prices. New scientific results on the impact of modern technologies on fruit quality parameters could increase consumption of apples.

The aim of this study was to evaluate the influence of different orchard management technologies (crop load, planting distance between apple-trees and apple-tree growth regulation), biological factors (fruit location in apple-tree canopy) and growing site on triterpene concentrations in apple fruits.

\section{Materials and methods}

The effect of different growing and management technologies on the triterpene content in apple -tree (Malus $\times$ domestica Borkh.) fruit was investigated in the experimental orchards of the Institute of Horticulture, Lithuanian Research Centre for Agriculture and Forestry in 2015 and 2016. Additionally, apple samples, grown at Research Institute of Horticulture in Skierniewice, Poland and Polli Horticultural Research Centre, Estonia, were investigated for the effect of the geographical location on the accumulation of triterpene compounds.

Growing and management technologies. Effect of crop load. Three crop load levels: 4, 8 and 12 fruits per unit of trunk cross-sectional area (fruits $\mathrm{cm}^{-2}$ TCSA), were established by hand thinning before flowering in early May at the pink bud stage. Fruitlets remaining after the June drop were counted and thinned according to the crop load level. Apple-trees of cultivar 'Ligol' on rootstock P 60 were planted at the distance $3.5 \times 1.25 \mathrm{~m}$ in 2011. The trial was established in four replicates with two apple-trees per replicate. The experiment was laid out in a fully randomized design. Ten fruits per each tree (20 fruits per replicate) from different canopy places were randomly selected for the analysis at optimum harvest time.
Effect of fruit location in apple-tree canopy. Investigations were carried out with an apple-tree cultivar 'Ligol' on rootstock P 60 planted at the distance $4 \times 1.25 \mathrm{~m}$ in 2002. Orchard row direction was SouthNorth. Four fruit locations in the apple-tree canopy were tested: 1) top of the apple-tree (above $2.3 \mathrm{~m}$ ), 2) lower inside part of the canopy (bottom) and 3-4) east and west sides of apple-trees. Apples for the last two treatments were harvested at $1.2-1.8 \mathrm{~m}$ above the ground. The trial was established in four replicates with four apple-trees per replicate. The experiment was laid out in a fully randomized design. Five fruits per each apple-tree (20 fruits per replicate) from the tested fruit locations in the canopy were randomly selected for the analysis at optimum harvest time.

Effect of planting distance. Investigations were carried out with an apple-tree cultivar 'Auksis' on rootstock P 60 planted in 2001. Apple-trees were planted at three distances: 1) $3 \times 1.50 \mathrm{~m}$, 2) $3 \times 1.00 \mathrm{~m}$ and 3) $3 \times 0.50 \mathrm{~m}$. According to the planting distance, apple-trees were trained as spindles, slender spindles and super spindles. The trial was established in four replicates with five apple-trees per replicate. Ten fruits per each apple-tree from different canopy places were randomly selected at optimum harvest time. From the bulk of 50 fruits from each replication 20 fruits were randomly selected for the analysis.

Effect of apple-tree vegetative growth regulation. Investigations were carried out with an apple-tree cultivar 'Rubin' on rootstock P 60 planted at the distance $4 \times 1.5 \mathrm{~m}$ in 1999 . Four treatments of apple-tree vegetative growth control were established: 1) control, where apple-trees were maintained according to intensive technologies; 2) apple-tree trunk incision before flowering by chain saw at the level of $20 \mathrm{~cm}$ above the ground from one side and $60 \mathrm{~cm}$ level from the other side; 3 ) application of growth regulator prohexadionecalcium at a rate of $2.5 \mathrm{~kg} \mathrm{ha}{ }^{-1}$ immediately after flowering when new shoots had 5 leaves; 4) summer pruning performed in the middle of August.

Effect of geographical location. Two appletree cultivars 'Auksis' and 'Ligol' grown on rootstock B.396 were tested. Fruit samples of each cultivar were collected at the Research Institute of Horticulture located at Skierniewice $\left(51^{\circ} 58^{\prime} \mathrm{N}, 20^{\circ} 09^{\prime} \mathrm{E}\right)$, Poland, Institute of Horticulture, Lithuanian Research Centre for Agriculture and Forestry in Babtai $\left(55^{\circ} 60^{\prime} \mathrm{N}, 23^{\circ} 48^{\prime} \mathrm{E}\right)$ and at Polli Research Centre $\left(58^{\circ} 67^{\prime} \mathrm{N}, 25^{\circ} 33^{\prime} \mathrm{E}\right)$, Institute of Agricultural and Environmental Sciences of the Estonian University of Life Sciences. The orchards are located $\sim 400 \mathrm{~km}$ apart, at a similar distance from the Baltic Sea. The orchards were planted in the spring of 2005 under a uniform design in three replicates with five apple-trees per replicate. Planting distance was $4 \times 1.5 \mathrm{~m}$. Apple-trees were trained as slender spindle. Climate conditions and soil properties differed between the trial locations. In Poland: soil - deep sandy-loam, $\mathrm{pH}-6.7$, humus $-1.4 \%$, $\mathrm{P}_{2} \mathrm{O}_{5}-195 \mathrm{mg} \mathrm{kg}^{-1}, \mathrm{~K}_{2} \mathrm{O}-190 \mathrm{mg} \mathrm{kg}^{-1}$, average annual 
precipitation: $550 \mathrm{~mm}$, average sum of active temperatures: $2550^{\circ}$. In Lithuania: soil - clay loam, $\mathrm{pH}-7.3$, humus $2.8 \%, \mathrm{P}_{2} \mathrm{O}_{5}-255 \mathrm{mg} \mathrm{kg}^{-1}, \mathrm{~K}_{2} \mathrm{O}-230 \mathrm{mg} \mathrm{kg}^{-1}$, average annual precipitation $-630 \mathrm{~mm}$, average sum of active temperatures $\left(>10^{\circ} \mathrm{C}\right)-2300^{\circ}$. In Estonia: soil - clay loam, $\mathrm{pH}-5.3$, humus $-2.0 \%, \mathrm{P}_{2} \mathrm{O}_{5}-130 \mathrm{mg} \mathrm{kg}^{-1}, \mathrm{~K}_{2} \mathrm{O}$ $-223 \mathrm{mg} \mathrm{kg}^{-1}$, average annual precipitation $-455 \mathrm{~mm}$, average sum of active temperatures $-1930^{\circ} .50$ randomly selected apples were harvested at $1.2-1.8 \mathrm{~m}$ above the ground from 5 apple-trees from each experimental plot at the optimal harvest time individually established for every cultivar and country.

Chemical analysis. Sample preparation. Each apple was peeled with a semi-automatic peeling machine AS 4 (Kronen GmbH, Germany). The peels were immediately frozen in a freezer $\left(\right.$ at $\left.-35^{\circ} \mathrm{C}\right)$ with air circulation and then lyophilized with a sublimator Zirbus $3 \times 4 \times 5$ (ZIRBUS technology GmbH, Germany) at a pressure of 0.01 mbar (condenser temperature $-85^{\circ} \mathrm{C}$ ). The lyophilized apple peels were ground to fine powder by using a knife mill GM (Retsch GmbH, Germany). Loss on drying before analysis was determined by drying the apple peel lyophilizate in a laboratory drying oven to complete evaporation of water and volatile compounds (temperature $-105^{\circ} \mathrm{C}$, the difference in weight between measurements - up to $0.01 \mathrm{~g}$ ) and by calculating the difference in raw material weight before and after drying. The data were recalculated for absolute dry weight (DW).

Extraction. An amount of $1 \mathrm{~g}$ of lyophilized apple peel powder (exact weight) was weighed, added to $10 \mathrm{~mL}$ of acetone $(100 \%, \mathrm{v} / \mathrm{v})$, and extracted in a Sonorex Digital $10 \mathrm{P}$ ultrasonic bath (Bandelin Electronic $\mathrm{GmbH}$ \& Co. KG, Germany) for 10 minutes. The conditions of extraction (type of extraction, duration, temperature, solvent and its concentration) were chosen considering the results of extraction optimization. The extract obtained was filtered through a paper filter; the apple peel lyophilizate on the filter was washed with acetone $(100 \%, v / v)$ in a $10-\mathrm{mL}$ flask. The extract was filtered through a membrane filter with a pore size of $0.22 \mu \mathrm{m}$ (Carl Roth GmbH, Germany).

Instrumentation and chromatographic conditions. A chromatograph Waters 2695 equipped with a detector Waters 2998 PDA ("Waters", USA) was used for high-performance liquid chromatography (HPLC) analysis. Chromatographic separation was managed, chromatograms were recorded, and data were processed with the software Empower ${ }^{\circledR}$ v.3.0 ("Waters"). Chromatographic separations were carried out by using an $\operatorname{ACE}^{\circledR}\left(5 \mu \mathrm{m}, \mathrm{C}_{18}, 250 \times 4.6 \mathrm{~mm}\right)$ column. The column was operated at a constant temperature of $25^{\circ} \mathrm{C}$. The volume of the extract being investigated was $10 \mu \mathrm{L}$. The flow rate was $1 \mathrm{~mL} \mathrm{~min}^{-1}$, and isocratic elution was used. The mobile phase consisted of $88 \%$ acetonitrile (solvent A) and $12 \%$ water (solvent B). The duration of the analysis was 15 minutes. The identification of the chromatographic peaks was achieved by comparing the retention times and spectral characteristics $(\lambda=200$ $400 \mathrm{~nm}$ ) of the eluting peaks with those of reference compounds. The compounds identified were confirmed by spiking the sample with the standard compound and monitoring the changes in the peak shape and spectral characteristics. For quantitative analysis, a calibration curve was obtained by injection of known concentrations of different standard compounds. The concentrations of triterpenic compounds, identified in the apple peel extracts, were within the limits of calibration curves. Triterpenic compounds were quantified at $205 \mathrm{~nm}$. The concentration of triterpene compounds was calculated based on the peak areas by using standard compounds (Fig.). All trials were repeated three times (biological replicates) each year.

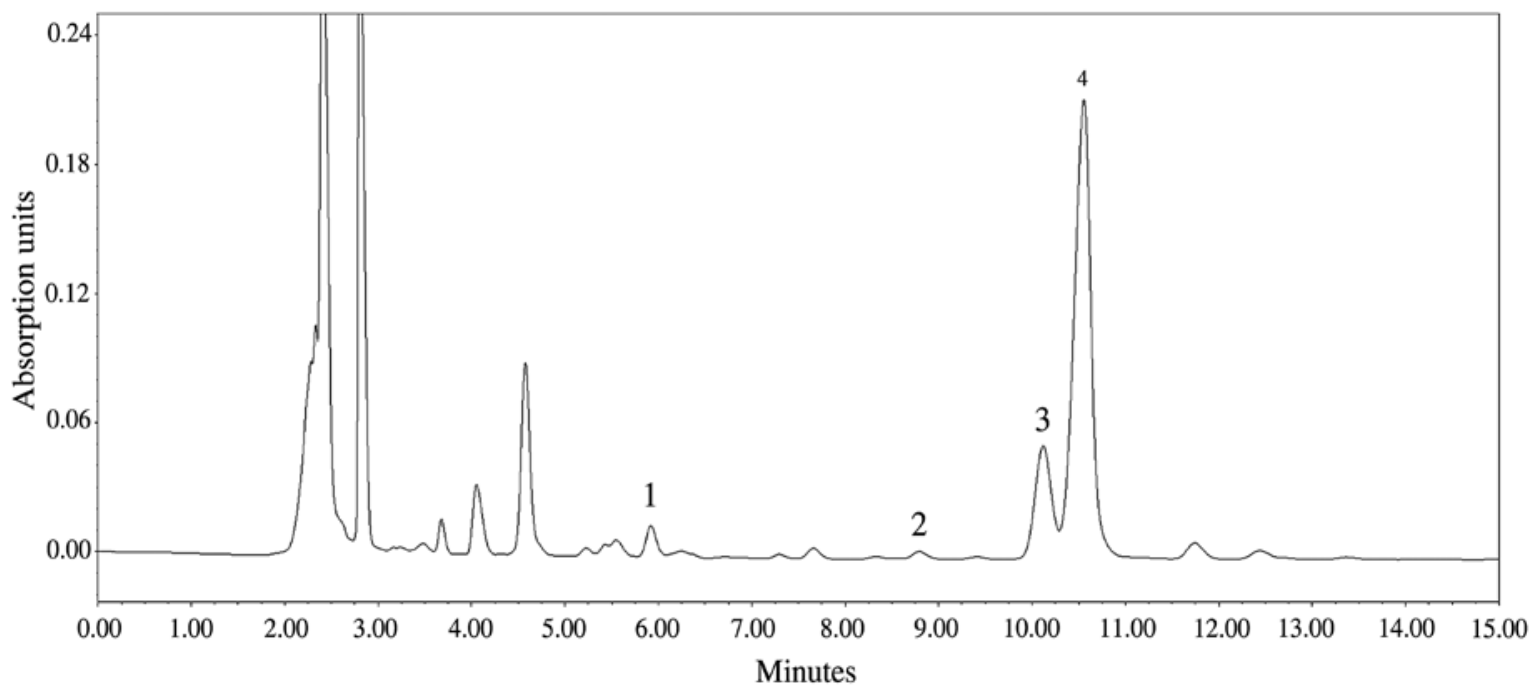

Note. Numbers indicate the peaks of analytes: 1 - corosolic acid, 2 - betulinic acid, 3 - oleonolic acid, 4 - ursolic acid.

Figure. Chromatogram of acetone extracts of apple peel sample 
Statistical analysis. The data on the main traits were subjected to the analysis of variance $(A N O V A)$. Results in tables are presented as means, since there were no year / treatment interactions. Significance of differences between treatments was estimated by Tukey's HSD (honest significant difference) test at $P<0.05$.

\section{Results}

Effect of crop load on triterpene content. Apples harvested from the trees, that had higher number of fruits, accumulated larger quantities of all investigated triterpenic compounds (Table 1). With the highest crop load (12 fruits $\mathrm{cm}^{-2}$ TCSA) this difference was statistically significant for all investigated triterpene compounds.

Table 1. The effect of crop load on the content ( $\mathrm{mg} \mathrm{g}^{-1}$ dry weight) of triterpenic acids in the fruit of cultivar 'Ligol' (2015-2016)

\begin{tabular}{lccc}
\hline \multirow{2}{*}{ Compounds } & \multicolumn{3}{c}{$\begin{array}{c}\text { Crop load, fruits cm-2 } \\
\text { trunk cross-sectional area }\end{array}$} \\
\cline { 2 - 4 } & 4 & 8 & 12 \\
\hline Corosolic acid & $1.48 \mathrm{~b}$ & $1.48 \mathrm{~b}$ & $1.70 \mathrm{a}$ \\
Betulinic acid & $0.10 \mathrm{~b}$ & $0.11 \mathrm{~b}$ & $0.17 \mathrm{a}$ \\
Oleonolic acid & $1.81 \mathrm{~b}$ & $1.97 \mathrm{~b}$ & $2.29 \mathrm{a}$ \\
Ursolic acid & $8.78 \mathrm{~b}$ & $8.93 \mathrm{~b}$ & $10.13 \mathrm{a}$ \\
\hline \multicolumn{1}{c}{ Total } & $12.17 \mathrm{~b}$ & $12.48 \mathrm{~b}$ & $14.28 \mathrm{a}$ \\
\hline
\end{tabular}

Note. The different letters in the same line indicate statistically significant differences between the individual compounds in the apple peel samples $(p<0.05)$.

Effect of fruit location in apple-tree canopy on triterpene content. Apples, harvested from the bottom of an apple-tree, accumulated the highest amount of total triterpene compounds (Table 2). Betulinic acid concentration was significantly higher in these apples. A lower amount of the investigated triterpenes was found in fruits, picked from the top position of an apple-tree. Fruits from bottom and east side accumulated more triterpenes than fruits from top and west side.

Table 2. The effect of fruit location in the apple-tree canopy on the content ( $\mathrm{mg} \mathrm{g}^{-1}$ dry weight) of triterpenic acids in the fruit of cultivar 'Ligol' (2015-2016)

\begin{tabular}{ccccc}
\hline \multirow{2}{*}{ Compounds } & \multicolumn{4}{c}{ Fruit location in apple-tree canopy } \\
\cline { 2 - 5 } & bottom & top & east & west \\
\hline Corosolic acid & $1.44 \mathrm{a}$ & $1.25 \mathrm{~b}$ & $1.34 \mathrm{ab}$ & $1.41 \mathrm{ab}$ \\
Betulinic acid & $0.14 \mathrm{a}$ & $0.10 \mathrm{c}$ & $0.12 \mathrm{~b}$ & $0.09 \mathrm{c}$ \\
Oleonolic acid & $2.13 \mathrm{a}$ & $1.89 \mathrm{ab}$ & $1.95 \mathrm{ab}$ & $1.77 \mathrm{~b}$ \\
Ursolic acid & $10.05 \mathrm{a}$ & $8.65 \mathrm{~b}$ & $8.90 \mathrm{ab}$ & $8.65 \mathrm{~b}$ \\
\hline Total & $13.76 \mathrm{a}$ & $11.89 \mathrm{~b}$ & $12.31 \mathrm{ab}$ & $11.92 \mathrm{~b}$ \\
\hline
\end{tabular}

Explanation under Table 1
Effect of apple-tree growth regulation on triterpene content. Of all the treatments applied, only summer pruning had a positive effect on the accumulation of all triterpenic compounds in apple fruits (Table 3). Trunk incision by chain saw from both sides of the trunk had a negative effect on triterpene concentration in apples - it was significantly lower in comparison to the control samples. Spraying apple-trees with a growth regulator prohexadione-calcium had no effect on triterpene concentration, except for betulinic acid, which increased in comparison with the control samples.

Table 3. The effect of the apple-tree growth regulation method on the content ( $\mathrm{mg} \mathrm{g}^{-1}$ dry weight) of triterpenic acids in the fruit of cultivar 'Rubin' (2015-2016)

\begin{tabular}{ccccc}
\hline \multirow{2}{*}{ Compounds } & \multicolumn{4}{c}{ Apple-tree growth regulation method } \\
\cline { 2 - 5 } & control & $\begin{array}{c}\text { trunk } \\
\text { incision }\end{array}$ & $\begin{array}{c}\text { prohexadione- } \\
\text { calcium }\end{array}$ & $\begin{array}{c}\text { summer } \\
\text { pruning }\end{array}$ \\
\hline Corosolic acid & $1.33 \mathrm{a}$ & $1.15 \mathrm{~b}$ & $1.29 \mathrm{ab}$ & $1.42 \mathrm{a}$ \\
Betulinic acid & $0.19 \mathrm{c}$ & $0.15 \mathrm{~d}$ & $0.24 \mathrm{~b}$ & $0.32 \mathrm{a}$ \\
Oleonolic acid & $2.10 \mathrm{ab}$ & $1.85 \mathrm{~b}$ & $2.02 \mathrm{~b}$ & $2.35 \mathrm{a}$ \\
Ursolic acid & $9.06 \mathrm{a}$ & $7.70 \mathrm{~b}$ & $8.81 \mathrm{ab}$ & $9.63 \mathrm{a}$ \\
\hline Total & $12.68 \mathrm{a}$ & $10.85 \mathrm{~b}$ & $12.35 \mathrm{ab}$ & $13.73 \mathrm{a}$ \\
\hline
\end{tabular}

Explanation under Table 1

Effect of apple-tree planting distance on triterpene content. More triterpenes were accumulated when the trees were planted at high densities (Table 4). The amount of total triterpenes depended on the planting distances between trees. Lower triterpene concentrations were found in the fruits from trees that had been planted at the widest distance. Only betulinic acid content was higher in these samples, but it had a small influence on the total concentration of triterpenes.

Table 4. The effect of apple-tree planting distance on the content ( $\mathrm{mg} \mathrm{g}^{-1}$ dry weight) of triterpenic acids in the fruit of cultivar 'Auksis' (2015-2016)

\begin{tabular}{cccc}
\hline \multirow{2}{*}{ Compounds } & \multicolumn{2}{c}{ Apple-tree planting distance m } \\
\cline { 2 - 4 } & $3 \times 1.50$ & $3 \times 1.00$ & $3 \times 0.50$ \\
\hline Corosolic acid & $0.40 \mathrm{a}$ & $0.42 \mathrm{a}$ & $0.43 \mathrm{a}$ \\
Betulinic acid & $0.22 \mathrm{a}$ & $0.16 \mathrm{~b}$ & $0.17 \mathrm{~b}$ \\
Oleonolic acid & $2.05 \mathrm{~b}$ & $2.34 \mathrm{ab}$ & $2.57 \mathrm{a}$ \\
Ursolic acid & $9.71 \mathrm{a}$ & $10.77 \mathrm{a}$ & $10.86 \mathrm{a}$ \\
\hline Total & $12.38 \mathrm{a}$ & $13.69 \mathrm{a}$ & $14.04 \mathrm{a}$ \\
\hline
\end{tabular}

Explanation under Table 1

Effect of apple-tree geographical location on triterpene content. Significantly lower amount of triterpenic compounds was accumulated in the apples of the cultivar 'Auksis' from Poland (Table 5). This trend was observed in both years. 
Table 5. The effect of apple-tree geographical location on the content ( $\mathrm{mg} \mathrm{g}^{-1}$ dry weight) of triterpenic acids in the fruit of cultivar 'Auksis'

\begin{tabular}{ccccc}
\hline \multirow{2}{*}{ Year } & Compounds & \multicolumn{3}{c}{ Apple-tree geographical location } \\
\cline { 3 - 5 } & & $\begin{array}{c}\text { Skierniewice, } \\
\text { Poland }\end{array}$ & $\begin{array}{c}\text { Babtai, } \\
\text { Lithuania }\end{array}$ & $\begin{array}{c}\text { Polli, } \\
\text { Estonia }\end{array}$ \\
\hline \multirow{2}{*}{2015 corosolic acid } & $0.18 \mathrm{c}$ & $0.28 \mathrm{~b}$ & $0.45 \mathrm{a}$ \\
betulinic acid & $0.07 \mathrm{~b}$ & $0.08 \mathrm{ab}$ & $0.09 \mathrm{a}$ \\
oleonolic acid & $1.06 \mathrm{c}$ & $1.55 \mathrm{~b}$ & $1.88 \mathrm{a}$ \\
ursolic acid & $4.83 \mathrm{c}$ & $7.17 \mathrm{~b}$ & $9.29 \mathrm{a}$ \\
\hline Total & $6.14 \mathrm{c}$ & $9.08 \mathrm{~b}$ & $11.71 \mathrm{a}$ \\
\hline corosolic acid & $0.41 \mathrm{c}$ & $0.68 \mathrm{a}$ & $0.53 \mathrm{~b}$ \\
betulinic acid & $0.14 \mathrm{~b}$ & $0.18 \mathrm{a}$ & $0.11 \mathrm{c}$ \\
oleonolic acid & $1.75 \mathrm{c}$ & $2.65 \mathrm{a}$ & $2.04 \mathrm{~b}$ \\
ursolic acid & $9.33 \mathrm{~b}$ & $12.18 \mathrm{a}$ & $9.78 \mathrm{~b}$ \\
\hline Total & $11.62 \mathrm{~b}$ & $15.69 \mathrm{a}$ & $12.45 \mathrm{~b}$ \\
\hline corosolic acid & $0.29 \mathrm{~b}$ & $0.48 \mathrm{a}$ & $0.49 \mathrm{a}$ \\
betulinic acid & $0.11 \mathrm{a}$ & $0.13 \mathrm{~b}$ & $0.10 \mathrm{a}$ \\
Average oleonolic acid & $1.41 \mathrm{~b}$ & $2.10 \mathrm{a}$ & $1.96 \mathrm{a}$ \\
ursolic acid & $7.08 \mathrm{~b}$ & $9.68 \mathrm{a}$ & $9.54 \mathrm{a}$ \\
\hline Total & $8.88 \mathrm{~b}$ & $12.39 \mathrm{a}$ & $12.08 \mathrm{a}$ \\
\hline
\end{tabular}

Explanation under Table 1

The apples of the cultivar 'Ligol' from Polish, Lithuanian and Estonian trial orchards did not significantly differ in the total triterpenes content (Table 6).

Table 6. The effect of apple-tree geographical location on the content ( $\mathrm{mg} \mathrm{g}^{-1}$ dry weight) of triterpenic acids in the fruit of cultivar 'Ligol'

\begin{tabular}{ccccc}
\hline \multirow{2}{*}{ Year } & Compounds & \multicolumn{3}{c}{ Apple-tree geographical location } \\
\cline { 2 - 5 } & & $\begin{array}{c}\text { Skierniewice, } \\
\text { Poland }\end{array}$ & $\begin{array}{c}\text { Babtai, } \\
\text { Lithuania }\end{array}$ & $\begin{array}{c}\text { Polli, } \\
\text { Estonia }\end{array}$ \\
\hline \multirow{2}{*}{2015 corosolic acid } & $1.06 \mathrm{~b}$ & $1.35 \mathrm{a}$ & $0.98 \mathrm{~b}$ \\
betulinic acid & $0.12 \mathrm{~b}$ & $0.15 \mathrm{a}$ & $0.12 \mathrm{~b}$ \\
oleonolic acid & $1.76 \mathrm{~b}$ & $2.05 \mathrm{a}$ & $1.96 \mathrm{ab}$ \\
& ursolic acid & $8.46 \mathrm{a}$ & $9.29 \mathrm{a}$ & $8.93 \mathrm{a}$ \\
\hline Total & $11.40 \mathrm{a}$ & $12.82 \mathrm{a}$ & $11.99 \mathrm{a}$ \\
\hline \multirow{2}{*}{ corosolic acid } & $1.28 \mathrm{~b}$ & $1,76 \mathrm{a}$ & $0,85 \mathrm{c}$ \\
betulinic acid & $0.12 \mathrm{~b}$ & $0,16 \mathrm{a}$ & $0,14 \mathrm{~b}$ \\
oleonolic acid & $2.03 \mathrm{~b}$ & $2.44 \mathrm{a}$ & $2.66 \mathrm{a}$ \\
ursolic acid & $10.80 \mathrm{ab}$ & $9.85 \mathrm{~b}$ & $11.28 \mathrm{a}$ \\
\hline Total & $14.23 \mathrm{a}$ & $14.21 \mathrm{a}$ & $14.93 \mathrm{a}$ \\
\hline \multirow{2}{*}{ corosolic acid } & $1.17 \mathrm{c}$ & $1.55 \mathrm{a}$ & $0.91 \mathrm{~b}$ \\
betulinic acid & $0.12 \mathrm{~b}$ & $0.15 \mathrm{a}$ & $0.13 \mathrm{~b}$ \\
Average oleonolic acid & $1.89 \mathrm{~b}$ & $2.24 \mathrm{a}$ & $2.31 \mathrm{a}$ \\
ursolic acid & $9.63 \mathrm{a}$ & $9.57 \mathrm{a}$ & $10.10 \mathrm{a}$ \\
\hline Total & $12.81 \mathrm{a}$ & $13.52 \mathrm{a}$ & $13.46 \mathrm{a}$ \\
\hline
\end{tabular}

Explanation under Table 1
Also, it was noticed that cultivar 'Ligol' accumulated more triterpenes than 'Auksis' apples, and mainly it was due to the corosolic acid, which was found at much higher concentrations in 'Ligol' apples.

\section{Discussion}

Our study determined the quantities of the four triterpenic compounds: corosolic, betulinic, oleonolic and ursolic acids, which are the most common triterpenes found in apple peel. However, a total of thirteen triterpenoids have been identified in apple peel (He, Liu, 2007). The highest concentrations, found in apple peel, was of oleonolic and ursolic acids (Cefarelli et al., 2006; Jäger et al., 2009), which agrees with the findings of our study. Compared with apple flesh, apple peel shows more potent antioxidant activity and antiproliferative activity (Wolfe et al., 2003), and this can be linked to triterpenes, because they are found mostly in peel.

Regardless of the numerous investigations of secondary metabolites, the impact of new growing technologies or separate technological means on fruit internal quality has not been explored yet. Until now, investigations of bioactive compounds and especially phenolics in apples have been limited to determination of differences between cultivars or growing systems (organic and integrated) or to the impact of light, apple-tree nutrition and some stress factors as drought, pathogens or soil salinity (Awad et al., 2001; Vieira et al., 2009; Lanauskas et al., 2017).

In previous investigations, it has been found that crop load has a significant effect on plant nutritional status and phytohormones (Samuolienè et al., $2016 \mathrm{a}$; b), it also influences the concentration of anthocyanins in fruits (Jakopic et al., 2009). Very contrasting data on crop load influence on apple fruit quality have been obtained by various researchers (Viškelis, Kviklys, 2017). This confirms the idea that fruit quality is determined by many different growing technologies and biological aspects, including cultivar, growing site, and other factors.

Apple-tree growth regulation, such as spraying with a growth regulator prohexadione-calcium or summer pruning, is a common practise in commercial orchards, but fruit quality is mostly determined by the external quality parameters, fruit colour, size and firmness, and basic internal quality parameters, such as soluble solids, sugar content and acidity (Zadravec et al., 2008; Ashraf, Ashraf, 2014). There are few research data available on the relationship between bioactive compounds, such as phenolics or triterpenes, and apple-tree growth regulation. Our data suggest that summer pruning increases triterpene accumulation in apples, while trunk incision has a negative effect.

The effect of fruit location in apple-tree canopy on fruit quality has been researched in much more detail: fruits from outer-canopy had higher phenolic content, higher fresh weight and higher soluble solids content. Research on the effects of location within the canopy 
on both primary and secondary metabolites showed the importance of light exposure on apple fruit quality (Nilsson, Gustavsson, 2007; Drogoudi, Pantelidis, 2011; Unuk et al., 2012; Feng et al., 2014). In the case of triterpenes, our study indicated higher accumulation in fruits harvested from the bottom of the apple-tree - in the shaded zone of the apple-tree canopy.

Our research data show that the concentration of triterpene compounds in most cases could be attributed to solar irradiation and is negatively related to the amount of received sunlight. In Lv et al. (2015) research, apple cultivars with obvious sun-exposed and shaded sides were investigated for triterpene concentration in both sides of the fruit. The results showed that oleonolic and ursolic acid concentrations were higher in the peel of the shaded side than of the sun-exposed side. This trend was also observed in grapefruits (McDonald et al., 1993). The data of some researchers show that differences between shaded ant sun-exposed fruits cause different wax formation and its structure, which differs both qualitatively and quantitatively (Curry, 2008; Tahir et al., 2009). So, this fruit wax formation can be linked to triterpene concentration and explains higher triterpene concentration in cultivar 'Ligol' apples which has waxier peel than cultivars 'Auksis' and 'Rubin'.

\section{Conclusions}

1. The concentration of triterpenes in apple-tree (Malus $\times$ domestica Borkh.) fruits was directly correlated with the crop load: $17 \%$ more triterpenes were found at the highest crop load of 12 fruits $\mathrm{cm}^{-2}$ trunk crosssectional area (TCSA) compared with the lowest crop load of 4 fruits $\mathrm{cm}^{-2}$ TCSA.

2. Significantly the highest amount of triterpenes was found in the fruits harvested from the bottom and inside of the apple-tree canopy.

3. Apple-tree growth regulation by technological means affected synthesis of triterpenes. Trunk incision decreased the amount of total triterpenes by $16 \%$ compared to the control and by $26 \%$ compared to summer pruning.

4. A trend towards higher accumulation of triterpenes in fruits was found along with decreasing planting distances between the apple-trees.

5. Colder climate and a shorter vegetation period resulted in significantly higher triterpene concentrations in the fruits of the cultivar 'Auksis' grown in Lithuania and Estonia compared with those grown in Poland. The same trend, yet insignificant, was noticed for the cultivar 'Ligol'.

Received 03082017

Accepted 15012018

\section{References}

1. Andre C. M., Greenwood J. M, Walker E. G, Rassam M., Sullivan M., Evers D., Perry N. B., Laing W. A. 2012. Antiinflammatory procyanidins and triterpenes in 109 apple varieties. Journal of Agricultural and Food Chemistry, 60 (42): 10546-10554.

https://doi.org/10.1021/jf302809k

2. Ashraf N., Ashraf M. Summer pruning in fruit trees. 2014. African Journal of Agricultural Research, 9 (2): 206-210. https://doi.org/10.5897/AJAR2013.7916

3. Awad M., Wagenmakers P., de Jager A. 2001. Effects of light on flavonoids and chlorogenic acid levels in the skin of 'Jonagold' apples. Scientia Horticulturae, 88: 289-298. https://doi.org/10.1016/S0304-4238(00)00215-6

4. Cefarelli G., D’Abrosca B., Fiorentino A., Izzo A., Mastellone C., Pacifico S., Piscopo V. 2006. Free-radicalscavenging and antioxidant activities of secondary metabolites from reddened cv. Annurca apple fruits. Journal of Agricultural and Food Chemistry, 54 (3): 803-809.

https://doi.org/10.1021/jf052632g

5. Curry E. 2008. Effects of 1-MCP applied postharvest on epicuticular wax of apples (Malus domestica Borkh.) during storage. Journal of the Science of Food and Agriculture, 88 (6): 996-1006.

https://doi.org/10.1002/jsfa.3180

6. Drogoudi P. D., Pantelidis G. 2011. Effects of position on canopy and harvest time on fruit physico-chemical and antioxidant properties in different apple cultivars. Scientia Horticulturae, 129 (4): 752-760.

https://doi.org/10.1016/j.scienta.2011.05.036

7. Feng F., Li M., Ma F., Cheng L. 2014. Effects of location within the tree canopy on carbohydrates, organic acids, amino acids and phenolic compounds in the fruit peel and flesh from three apple (Malus $\times$ domestica) cultivars. Horticulture Research, 1: 14019. https://doi.org/10.1038/hortres.2014.19

8. Fontanay S., Grare M., Mayer J., Finance C., Duval R. E. 2008. Ursolic, oleanolic and betulinic acids: antibacterial spectra and selectivity indexes. Journal of Ethnopharmacology, 120 (2): 272-276. https://doi.org/10.1016/j.jep.2008.09.001

9. He X., Liu R. H. 2007. Triterpenoids isolated from apple peels have potent antiproliferative activity and may be partially responsible for apple's anticancer activity. Journal of Agricultural and Food Chemistry, 55 (11): 4366-4370. https://doi.org/10.1021/jf063563o

10. Hooge de I. E., Oostindjer M., Aschemann-Witzel J., Normann A., Loose S. M., Almli V. L. 2017. This apple is too ugly for me!: consumer preferences for suboptimal food products in the supermarket and at home. Food Quality and Preference, 56 (A): 80-92.

https://doi.org/10.1016/j.foodqual.2016.09.012

11. Ikeda Y., Murakami A., Ohigashi H. 2008. Ursolic acid: an anti- and pro-inflammatory triterpenoid. Molecular Nutrition and Food Research, 52 (1): 26-42. https://doi.org/10.1002/mnfr.200700389

12. Jäger S., Trojan H., Kopp T., Laszczyk M., Scheffler A. 2009. Pentacyclic triterpene distribution in various plants rich sources for a new group of multi-potent plant extracts. Molecules, 14 (6): 2016-2031.

https://doi.org/10.3390/molecules 14062016 
13. Jakopic J., Stampar F., Veberic R. 2009. The influence of exposure to light on the phenolic content of 'Fuji' apple. Scientia Horticulturae, 123 (2): 234-239. https://doi.org/10.1016/j.scienta.2009.09.004

14. Jang S.-M., Yee S.-T., Choi J., Choi M.-S., Do G.-M., Jeon S.-M., Yeo J., Kim M.-J., Seo K.-I., Lee M.-K. 2009. Ursolic acid enhances the cellular immune system and pancreatic $\beta$-cell function in streptozotocininduced diabetic mice fed a high-fat diet. International Immunopharmacology, 9 (1): 113-119. https://doi.org/10.1016/j.intimp.2008.10.013

15. Koch K., Ensikat H.-J. 2008. The hydrophobic coatings of plant surfaces: epicuticular wax crystals and their morphologies, crystallinity and molecular self-assembly. Micron, 39 (7): 759-772. https://doi.org/10.1016/j.micron.2007.11.010

16. Kviklys D., Liaudanskas M., Janulis V., Viškelis P., Rubinskienė M., Lanauskas J., Uselis N. 2014. Rootstock genotype determines phenol content in apple fruits. Plant, Soil and Environment, 60 (5): 234-240.

17. Lanauskas J., Kviklys D., Liaudanskas M., Janulis V., Uselis N., Viškelis J., Viškelis P. 2017. Lower nitrogen nutrition determined higher phenolic content of organic apples. Horticultural Science, 44 (3): 113-119.

https://doi.org/10.17221/50/2016-HORTSCI

18. Liaudanskas M., Viškelis P., Kviklys D., Raudonis R. Janulis V. 2015. A comparative study of phenolic content in apple fruits. International Journal of Food Properties, 18 (5): 945-953.

https://doi.org/10.1080/10942912.2014.911311

19. Lv Y., Tahir I. I., Olsson M. E. 2015. Factors affecting the content of the ursolic and oleanolic acid in apple peel: influence of cultivars, sun exposure, storage conditions, bruising and Penicillium expansum infection. Journal of the Science of Food and Agriculture, 96 (6): 2161-2169. https://doi.org/10.1002/jsfa.7332

20. McDonald R. E., Nordby H. E., McCollum T. G. 1993. Epicuticular wax morphology and composition are related to grapefruit chilling injury. HortScience, 28 (4): 311-312.

21. Muffler K., Leipold D., Scheller M. C., Haas C., Steingroewer J., Bley T., Neuhaus H. E., Mirata M. A., Schrader J., Ulber R. 2011. Biotransformation of triterpenes. Process Biochemistry, 46 (1): 1-15.

https://doi.org/10.1016/j.procbio.2010.07.015

22. Nilsson T., Gustavsson K.-E. 2007. Postharvest physiology of 'Aroma' apples in relation to position on the tree. Postharvest Biology and Technology, 43 (1): 36-46. https://doi.org/10.1016/j.postharvbio.2006.07.011

23. Qi S., Ding L., Tian K., Chen X., Hu Z. 2006. Novel and simple nonaqueous capillary electrophoresis separation and determination bioactive triterpenes in Chinese herbs. Journal of Pharmaceutical and Biomedical Analysis, 40 (1): 35-41. https://doi.org/10.1016/j.jpba.2005.06.003

24. Raudonè L., Raudonis R., Liaudanskas M., Janulis V., Viškelis P. 2017. Phenolic antioxidant profiles in the whole fruit, flesh and peel of apple cultivars grown in Lithuania. Scientia Horticulturae, 216: 186-192.

https://doi.org/10.1016/j.scienta.2017.01.005
25. Samuolienė G., Viškelienė A., Sirtautas R., Kviklys D. 2016 (a). Relationships between apple tree rootstock, crop-load, plant nutritional status and yield. Scientia Horticulturae, 211: 167-173.

https://doi.org/10.1016/j.scienta.2016.08.027

26. Samuolienė G., Čeidaitė A., Sirtautas R., Duchovskis P., Kviklys D. 2016 (b). Effect of crop load on phytohormones, sugars, and biennial bearing in apple trees. Biologia Plantarum, 60 (2): 394-400.

https://doi.org/10.1007/s10535-015-0581-3

27. Tahir I. I., Johansson E., Olsson M. E. 2009. Improvement of apple quality and storability by a combination of heat treatment and controlled atmosphere storage. HortScience, 44 (6): 1648-1654.

28. Unuk T., Tijskens L. M., Germšek B., Zadravec P., Vogrin A., Hribar J., Simčič M., Tojnko S. 2012. Effect of location in the canopy on the colour development of three apple cultivars during growth. Journal of the Science of Food and Agriculture, 92 (12): 2450-2458.

https://doi.org/10.1002/jsfa.5651

29. Vieira F. G., Borges G. D., Copetti C., Amboni R. D., Denardi F., Fett R. 2009. Physicochemical and antioxidant properties of six apple cultivars (Malus domestica Borkh.) grown in southern Brazil. Scientia Horticulturae, 122 (1): 421-425. https://doi.org/10.1016/j.scienta.2009.06.012

30. Viškelis J., Kviklys D. 2017. Crop load management in fruit-trees (review). Sodininkystė ir daržininkystè, 36 (1-2): 30-42 (in Lithuanian).

31. Wolfe K., Wu X., Liu R. H. 2003. Antioxidant activity of apple peels. Journal of Agricultural and Food Chemistry, 51 (3): 609-614. https://doi.org/10.1021/jf020782a

32. Zadravec P., Cmelik Z., Tojnko S., Unuk T., Schlauer B. 2008. Vegetative growth, yield and fruit quality of 'Gala' apple treated with Regalis (prohexadione-ca). Acta Horticulturae, 774: 287-290. https://doi.org/10.17660/ActaHortic.2008.774.38 
ISSN 1392-3196 / e-ISSN 2335-8947

Zemdirbyste-Agriculture, vol. 105, No. 1 (2018), p. 71-78

DOI $10.13080 / \mathrm{z}-\mathrm{a} .2018 .105 .010$

\title{
Triterpeninių rūgščių kiekị obuoliụ luobelèse lemia vaismedžių auginimo technologijos
}

\author{
J. Viškelis ${ }^{1}$, N. Uselis ${ }^{1,3}$, M. Liaudanskas², V. Janulis² ${ }^{2}$ P. Bielicki ${ }^{4}$, T. Univer ${ }^{5}$, J. Lepsis ${ }^{6}$, \\ D. Kviklys ${ }^{1}$
}

${ }^{1}$ Lietuvos agrarinių ir miškų mokslų centro Sodininkystès ir daržininkystės institutas

${ }^{2}$ Lietuvos sveikatos mokslų universiteto Medicinos akademija

${ }^{3}$ Aleksandro Stulginskio universitetas

${ }^{4}$ Lenkijos sodininkystės ir daržininkystès institutas

${ }^{5}$ Estijos gyvybès mokslų universiteto Žemès ūkio ir aplinkos mokslų instituto

Polli sodininkystès tyrimų centras

${ }^{6}$ Latvijos žemès ūkio universiteto Sodininkystès institutas

\section{Santrauka}

Nors atlikta daug antrinių metabolitų tyrimų, naujų auginimo technologijų ar atskirų technologinių priemonių įtaka vaisių vidinei kokybei, ypač triterpenų koncentracijai obuoliuose, dar nèra tyrinèta. Naminès obels (Malus $\times$ domestica Borkh.) auginimo technologijos ir auginimo vieta turi įtakos triterpenų kaupimuisi obuoliuose. Vaisių krūvio, vaisių vietos vaismedžių vainike, vaismedžių sodinimo atstumo, jų vegetatyvinio augumo reguliavimo ir geografinès augimo vietos įtaka triterpenų kiekiui obuoliuose 2015-2016 m. buvo tirta Lietuvos agrarinių ir miškų mokslų centro Sodininkystès ir daržininkystès institute. Obuolių žievelèse buvo nustatyti keturi triterpeniniai junginiai: korosolo, betulino, oleonolo ir ursolo rūgštys. Triterpenų kaupimasis obuoliuose tiesiogiai susijęs su vaisių krūviu. Obelyse esant dideliam vaisių krūviui (12 vaisių $\mathrm{cm}^{-2}$ kamieno skerspjūvio ploto (KSP)), obuoliai sukaupe $17 \%$ daugiau triterpenų nei vaismedžiai su mažu vaisių krūviu (4 vaisiai $\mathrm{cm}^{-2} \mathrm{KSP}$ ). Esmingai daugiau triterpenų sukaupè obuoliai, augę vaismedžio vainiko apačioje ir vidinejje dalyje. Triterpenų sintezei vaisiuose taip pat turẻjo ịtakos vaismedžių vegetatyvinio augumo reguliavimo priemonès. Kamieno ịpjovimas triterpenų kieki obuoliuose sumažino $16 \%$, lyginant su kontroliniu variantu, ir $26 \%$, lyginant su vasariniu genejjimu. Nustatyta tendencija, jog mažinant obelų sodinimo atstumą triterpenų kiekis obuoliuose didèja. Šaltesnis klimatas ir trumpesnè vegetacijos trukmè reikšmingai padidino triterpenų kiekị veislès 'Auksis' obuoliuose Lietuvoje bei Estijoje, lyginant su Lenkija. Panaši tendencija nustatyta ir tiriant veislès 'Ligol' obuolius.

Reikšminiai žodžiai: auginimo technologijos, bioaktyvūs junginiai, naminė obelis. 